\title{
A demonstration of an affinity between pyrite and organic matter in a hydrothermal setting
}

Paula Lindgren ${ }^{1 *}$, John Parnell ${ }^{2}$, Nils G Holm³ ${ }^{3}$ Curt Broman ${ }^{3}$

\begin{abstract}
One of the key-principles of the iron-sulphur world theory is to bring organic molecules close enough to interact with each other, using the surface of pyrite as a substrate in a hydrothermal setting. The present paper explores the relationship of pyrite and organic matter in a hydrothermal setting from the geological record; in hydrothermal calcite veins from Carboniferous limestones in central Ireland. Here, the organic matter is accumulated as coatings around, and through, pyrite grains. Most of the pyrite grains are euhedral-subhedral crystals, ranging in size from ca $0.1-0.5 \mathrm{~mm}$ in diameter, and they are scattered throughout the matrix of the vein calcite. The organic matter was deposited from a hydrothermal fluid at a temperature of at least $200^{\circ} \mathrm{C}$, and gives a Raman signature of disordered carbon. This study points to an example from a hydrothermal setting in the geological record, demonstrating that pyrite can have a high potential for the concentration and accumulation of organic materials.
\end{abstract}

\section{Introduction}

An important requirement for the origin of life is the concentration of organic compounds to allow interaction with each other and with other chemical species. An efficient mechanism for concentrating organic molecules is the adsorption onto mineral surfaces. There are several examples of minerals with strong affinities for the accumulation of organic matter. These include for instance clays [1], radioactive minerals [2], zeolites and feldspars [3] and sulphide minerals including pyrite $\left(\mathrm{FeS}_{2}\right)[4,5]$.

Here, we study the relationship between pyrite and migrated organic matter in the geological record, via hydrothermal deposits of the Irish Carboniferous, to assess the potential of pyrite acting as a substrate for organic matter.

\section{Pyrite and the iron-sulphur world}

The iron-sulphur world hypothesis for the origin of life was proposed by Wächtershäuser [5]. He suggests that the formation of pyrite $\left(\mathrm{FeS}_{2}\right)$ is the first energy source for life. The iron-sulphur world takes place in a hydrothermal setting, where iron- and sulphur-rich water produces abundant pyrite deposits. The formation of pyrite

\footnotetext{
* Correspondence: paula.lindgren@ges.gla.ac.uk

'Department of Geographical and Earth Sciences, University of Glasgow, Glasgow G12 8QQ, UK

Full list of author information is available at the end of the article
}

releases energy that could have been utilized during an autotrophic setting for the origin of life. The iron-sulphur world scenario for the origin of life stands in contrast to the heterotrophic origin of life in the "cold soup" theory [6,7]. In addition to an autotrophic origin of life, the iron-sulphur world also proposes pathways for the origin of cell membranes, the origin of DNA, and a range of other biochemical reactions essential to the origin of life [8].

A key-aspect of the iron-sulphur world theory is the adsorption of organic molecules to the surface of pyrite. The theory predicts that since the surface of pyrite is slightly positively charged, it would attract and bind negatively-charged organic molecules. The organic molecules would be connected to the surface of pyrite with weak ionic bonds, and therefore able to migrate rather freely around the surface of the pyrite crystal. This would make them more likely to interact and form more complex molecules. In fact, pyrite has a positive net charge in acid conditions below pH 6.8, which would be similar to conditions in an oxygen-depleted primordial environment, and a negative charge above pH 6.8 [9]. Several of the chemical reactions involved in the iron-sulphur world scenario have been tested successfully in the laboratory [9-13]. For example, pyrite strongly adsorbs adenine (one of the most important organic molecules for life) in a medium that simulates primordial aqueous environments, and the adsorption of adenine is enhanced 
in the presence of acetate (an organic precursor of complex metabolic pathways) and in an oxygen-depleted environment $[9,10]$.

To explore the relationship of pyrite and organic matter in a hydrothermal setting from the geological record, we have studied Carboniferous hydrothermal calcite veins from Mullaghwornia, Ireland, at a locality which retain both pyrite and organic matter.

\section{Pyrite and organic matter in the Irish Carboniferous}

The Carboniferous rocks of Ireland contain numerous sulphide ore deposits, which also at some localities include visible accumulations of organic matter [14], and in some cases concentrations of up to $8.6 \%$ organic carbon [15]. The sulphide deposits formed during late Devonian to early Carboniferous, about $340 \mathrm{Ma}$ ago, when Ireland suffered from rifting and extension during the break-up of an old red sandstone continent. This event was accompanied by widespread volcanism and the production of hydrothermal ore deposits, including the sulphides [16]. Also, at this period, a marine transgression gave rise to extensive carbonate deposition. These sediments, including bituminous limestone and black shale, are the most likely source of the organic matter in the sulphide deposits [14]. The sulphide deposits were precipitated widely in the Irish Carboniferous limestone terrain, and the sulphur was derived either from bacterial sulphate reduction of seawater, or from an abiogenic deep-seated hydrothermal source [17]. However, a study of sulphur isotopes from the orebody at Navan, central Ireland, shows that bacteria were responsible for the majority of the sulphide deposition there [18]. The sample locality for this study is the Mullaghwornia quarry at Ballymahon, central Ireland (Figure 1). This is an abandoned quarry exposing Dinantian (Lower Carboniferous) limestone, with a zone of hydrothermal calcite veining, containing pyrite and organic matter, cross-cutting a limestone-host.

\section{Results and discussion}

\section{Composition of hydrothermal veins from Mullaghwornia}

The fine-grained grey limestone at the Mullaghwornia quarry (Figure 1) is cross-cut by a zone of branching hydrothermal mineral veins. These mineral veins belong to a single large complex calcite vein, but the individual veins are typically a few $\mathrm{cm}$ in thickness (Figure 2). The veins are primarily composed of ca $5 \mathrm{~mm}$ in diameter sized euhedral calcite $\left(\mathrm{CaCO}_{3}\right)$ crystals, but they also contain pyrite $\left(\mathrm{FeS}_{2}\right)$ and abundant solid migrated organic matter (bitumen).

The pyrite crystals range in size from ca $0.1-0.5 \mathrm{~mm}$ in diameter and are scattered throughout the matrix of the calcite veins. The pyrite occurs as euhedral-subhedral cubes, or parts of cubes. In some instances, the

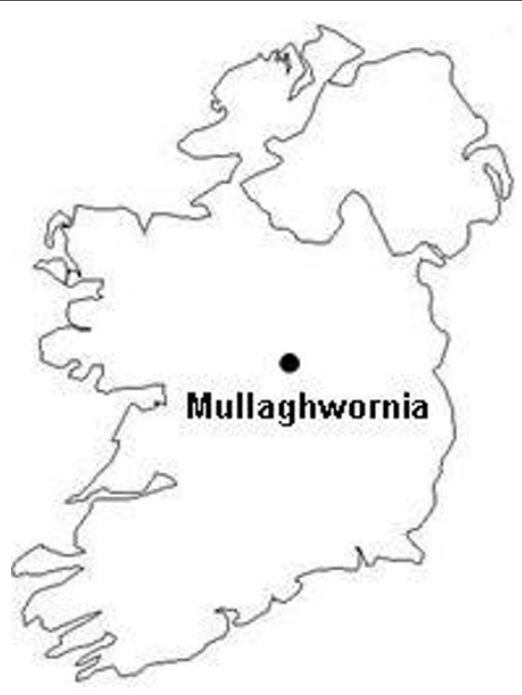

Figure 1 Outline map of Ireland showing the location of Mullaghwornia quarry at Ballymahon, central Ireland.

pyrite is brecciated with another sulphide phase, e.g. sphalerite $(\mathrm{ZnS})$. The organic matter appears as coatings around the pyrite crystals, but also as immiscible globules with curved boundaries in the calcite (Figure 3). The immiscibility morphology between the calcite and the organic matter suggests that the fluid precipitating the calcite, and the fluid precipitating the organics, coexisted. An alternative explanation is that the organic matter here may be secondary infillings, filling in dissolution cavities in the calcite, in which case the fluid that deposited the organic matter is later than the fluid that deposited the calcite. Further, in some instances the organic matter is cross-cutting the calcite crystals, here also suggesting a later deposition of the organics. The

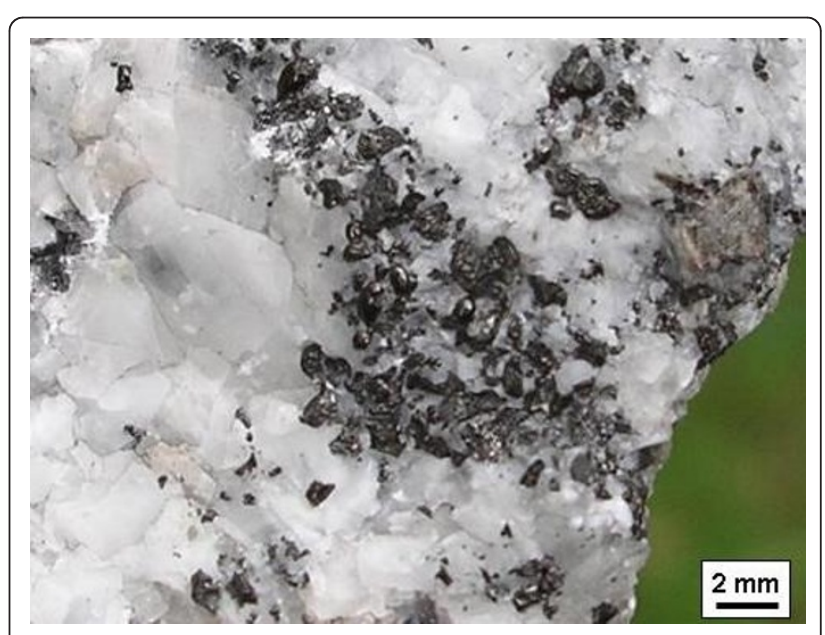

Figure 2 Hydrothermal calcite vein with globules of organic matter (black) from Mullaghwornia quarry. 


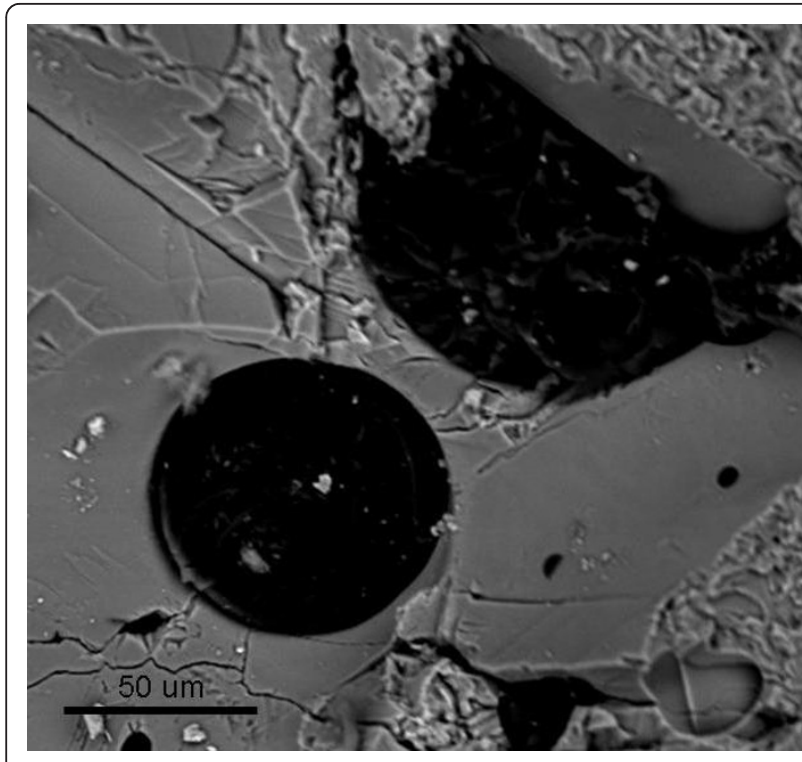

Figure 3 Backscattered SEM micrograph of a vein sample showing organic matter (black) appearing as immiscible globules with curved boundaries within the calcite (grey).

relationships are not straightforward, but most likely it was several pulses of hydrothermal fluids that went through the vein; initially fluids precipitating calcite and pyrite, followed by later fluids precipitating organic matter filling in dissolution cavities in the pre-existing calcite and forming coatings around the pyrite crystals, or later co-existing immiscible fluids precipitating more calcite and organics simultaneously. The source of organic matter is unknown, but probably it is derived from the surrounding sedimentary terrain, where the hot hydrothermal fluids generated the migration of organics.

\section{Interaction of pyrite and organic matter}

The occurrence of organic matter in hydrothermal ore deposits, including in sulphide deposits, is widespread [19]. Pyrite is the Earth's most abundant sulphide and occurs in a range of geological environments such as hydrothermal, sedimentary, and igneous settings. Pyrite regularly occurs as inclusions in migrated solid organic matter (bitumen). This relationship of pyrite and organics is not always straightforward, but can arise during direct precipitation and growth of the pyrite out of the bitumen [20]. It could also be an effect of the abrasion of pyrite from the surrounding rock by the migrating organics [21]. Pyrite in bitumen, and in other settings, can form both abiogenically or biogenically. Biogenic pyrite can form by sulphate-reducing bacteria producing $\mathrm{H}_{2} \mathrm{~S}$ from sea-water sulphate, where the $\mathrm{S}^{2-}$ may be incorporated into pyrite, or it could form from the reduction of sulphur released by biological degradation of the migrated bitumen itself. Pyrite framboids, raspberry-like aggregates of pyrite spheres, are also sometimes found in organic matter. It is believed that most pyrite framboids are abiogenic and indicators of fast crystal growth, but pyrite framboids can also be a result of microbial activity [22].

Here, in the hydrothermal setting of Mullaghwornia, there is indeed evidence of pyrite acting as an attractive substrate for the collection of organic matter; the majority of the pyrite crystals in the samples have organic coatings., Our observations are that twenty-four out of twenty-six observed pyrite crystals occurring in six blocks and thin sections from two different branches of the vein are coated with organic matter. The organic coatings are generally about 5-50 $\mu \mathrm{m}$ thick (Figure 4 ). In some cases the organic matter is invasive, i.e. penetrating and fracturing the pyrite crystals (Figure 5). This relationship makes it clear that the pyrite pre-dates the organic matter, i.e. the organics entered as a later phase than the pyrite and were subsequently adsorbed onto the surface of a pre-existing pyrite crystal. The sulphur isotopic composition, $\delta^{34} \mathrm{~S}\left({ }^{32} \mathrm{~S} /{ }^{34} \mathrm{~S}\right)$, of pyrite from Mullaghwornia is measured as $-1.9 \%$ [20]. The composition of early Carboniferous seawater is about $+15 \%$ [23]. The difference between the $\delta^{34} \mathrm{~S}$ of early Carboniferous seawater and the $\delta^{34} \mathrm{~S}$ of the Mullaghwornia pyrite gives a $\Delta S$ value of $+17 \%$. Unless the sulphate pool was restricted and closed, this value is indicative of a nonbiological fractionation process, i.e. the pyrite here probably has a deep-seated hydrothermal origin [24].

\section{Temperature of hydrothermal fluid}

The temperature condition of the hydrothermal fluid which precipitated the Mullaghwornia calcite was deduced through fluid inclusion microthermometry [25]. The calcite contains numerous primary, randomly distributed, aqueous fluid inclusions. The inclusions have a poorly developed negative crystal (rhombohedra) shape and their size varies from 3 to $22 \mu \mathrm{m}$. The inclusions are two-phased with a vapor and a liquid phase. There were no oil-bearing fluid inclusions in the studied calcite. Microthermometric analysis was made on a total of nine aqueous fluid inclusions and the results are presented in Table 1. The homogenization temperature (Th) was measured in the range $200^{\circ} \mathrm{C}$ to $275^{\circ} \mathrm{C}$, with homogenization to liquid in all inclusions. The Thrange provides minimum temperatures for the deposition of the Mullaghwornia calcite, as no correction for an unknown pressure could be taken into account. The homogenization temperatures from the Mullaghwornia calcite are within the higher portion of temperatures obtained from a number of other Irish carbonate-hosted ore deposits, where the temperatures range between $170^{\circ} \mathrm{C}$ to $240^{\circ} \mathrm{C}$ [26]. After freezing the Mullaghwornia 

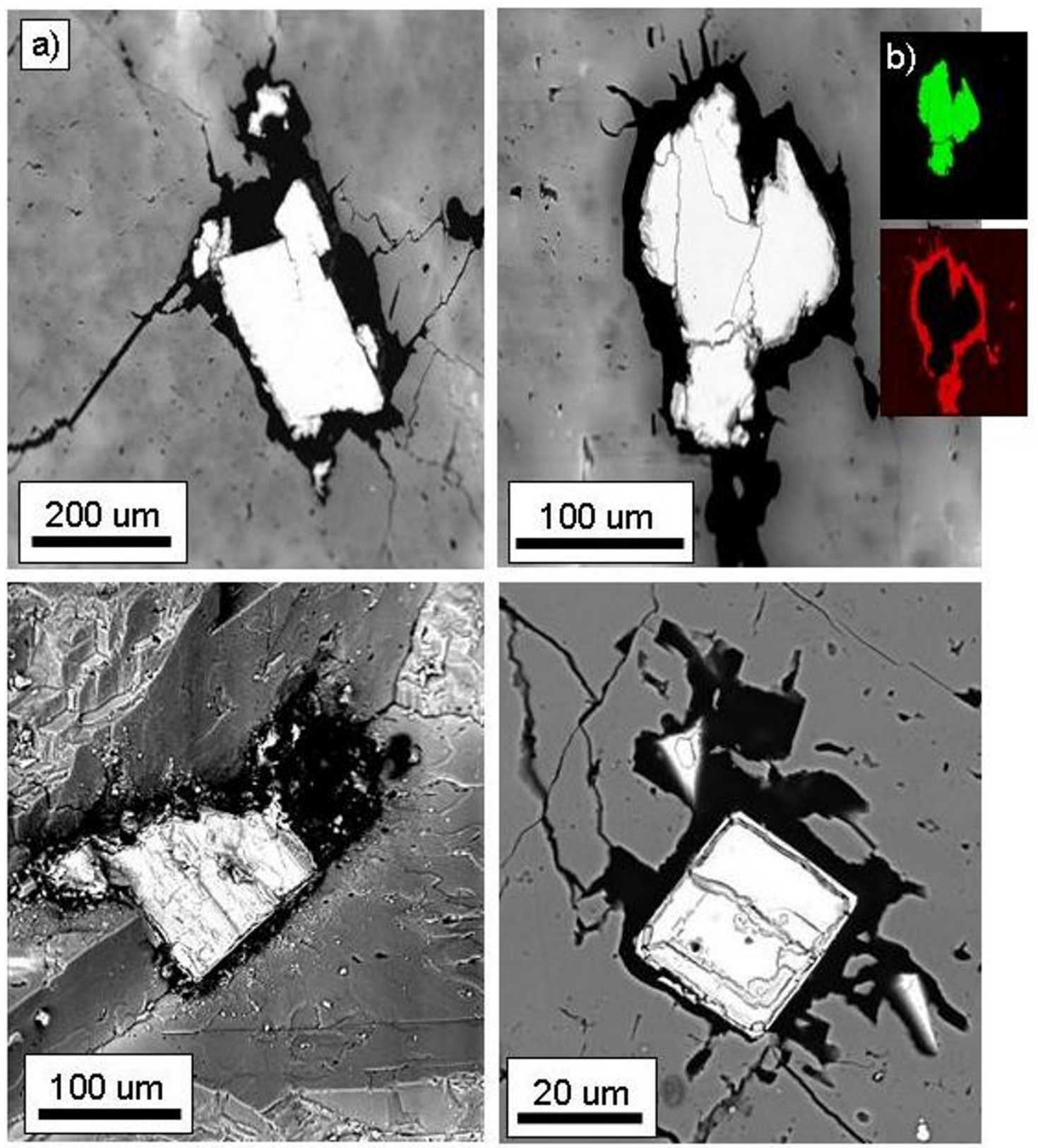

Figure 4 Pyrite crystals coated with organic matter. A) Backscattered SEM micrographs of pyrite crystals coated with organic matter in hydrothermal calcite veins from Mullaghwornia. The pyrite crystals appear white, the organic matter is black, and the calcite is grey. B) ED X-ray maps for sulphur (green) and carbon (red), with corresponding micrograph of pyrite and carbon.

inclusions, the first observed melting of ice ( $\mathrm{Tfm})$ occurred around $-48^{\circ} \mathrm{C}$ to $-50^{\circ} \mathrm{C}$. This coincides with the eutectic temperature for the $\mathrm{CaCl}_{2}-\mathrm{H}_{2} \mathrm{O}$ system [25]. The final ice melting temperature $(\mathrm{Tm})$ took place between $-15.0^{\circ} \mathrm{C}$ and $-16.2^{\circ} \mathrm{C}$, and corresponds to a salinity of about 18.6 to 19.5 wt. \% $\mathrm{NaCl}$ eq. [27]. The Irish carbonate-hosted ore deposits in [26] have a salinity of 12 to $18 \mathrm{wt} \% \mathrm{NaCl}$. Thus, the Mullaghwornia calcite was deposited from a relatively highly saline hydrothermal
$\mathrm{CaCl}_{2}$-dominated fluid at a temperature of at least $200^{\circ}$ $\mathrm{C}$, up to $275^{\circ} \mathrm{C}$. The Mullaghwornia locality is located in a limestone terrain, which gives ground waters that are oversaturated in calcium, and hence a $\mathrm{CaCl}_{2}$ brine [28].

\section{Crystallinity of carbon}

The fluid inclusion data reveals that the temperature of the hydrothermal fluid, and hence the temperature that the organic matter was exposed to, was at least $200^{\circ} \mathrm{C}$, 


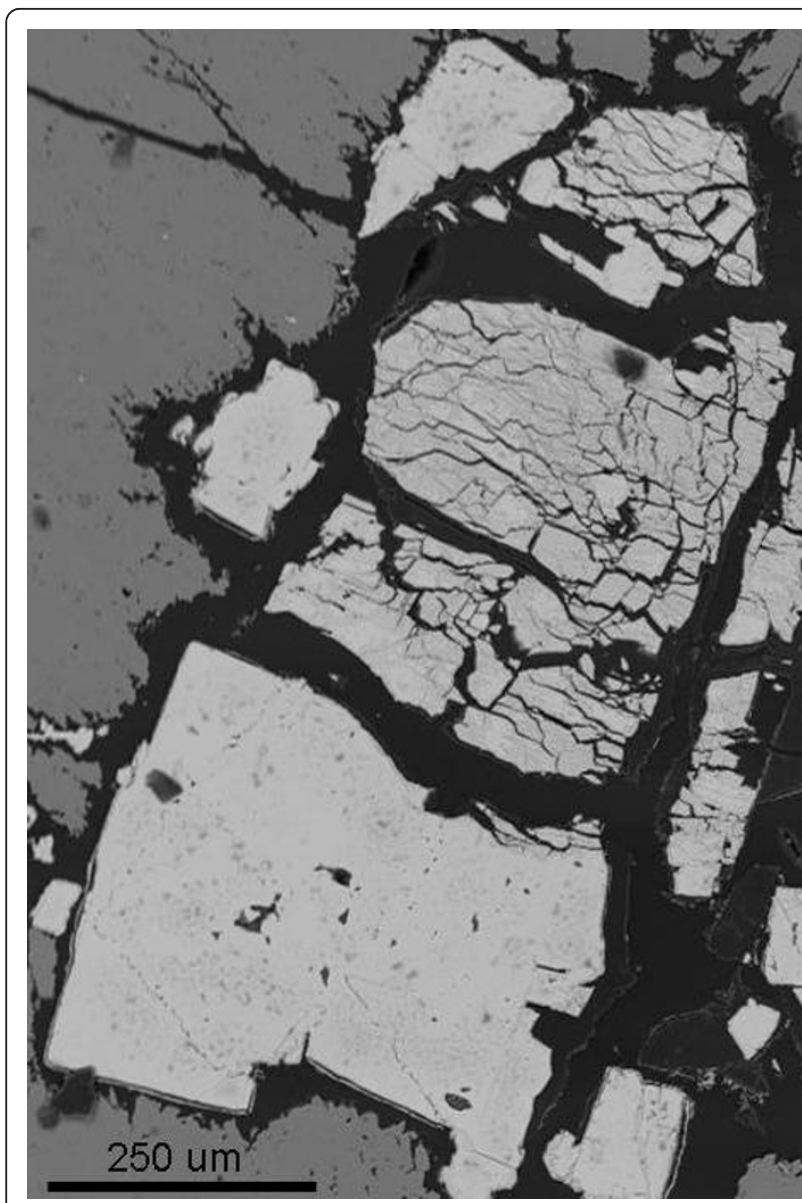

Figure 5 Backscattered SEM micrograph of a pyrite crystal coated with organic matter. In some cases the organic matter is invasive, i.e. penetrating and fracturing the pyrite crystals.

and up to $275^{\circ} \mathrm{C}$. The higher temperature the organics are subjected to, the higher the degree of order of the carbon (more graphitic), with exception of carbon included in a melt [29]. Temperatures of $200^{\circ} \mathrm{C}$ to $275^{\circ} \mathrm{C}$ should not be enough for graphite to form [30], thus we expect the carbon in the hydrothermal vein to be disordered. Raman spectroscopic analysis is used on carbonaceous matter to determine if the carbon is disordered or graphitic [31]. The Raman spectrum (in the first order region) of carbonaceous matter includes a graphite peak (G peak) at around $1580 \mathrm{~cm}^{-1}$. Disordered carbon also contains a peak at around $1360 \mathrm{~cm}^{-1}$ (D1 peak) and a peak at around $1620 \mathrm{~cm}^{-1}$ (D2). The D2 peak appears as a right shoulder on the $G$ peak, and in more disordered carbon it merges together with the $\mathrm{G}$ peak, causing a broad G +D2 peak around $1600 \mathrm{~cm}^{-1}$. The organic matter in the hydrothermal vein from Mullaghwornia gives a signature of poorly crystalline carbon (Figure 6); it has a D1 peak at around $1300 \mathrm{~cm}^{-1}$, and a merged $G$ and D2 peak at around $1600 \mathrm{~cm}^{-1}$.

\section{Implications for sulphide substrates on Mars and the early Earth}

This study is an example from the geological record showing that pyrite, the most abundant terrestrial sulphide, can act as a substrate for the concentration of organic matter, and that this evidence can be preserved and detected in the geological record. Sulphide substrates could also be important for carbon fixation on Mars. There is widespread evidence that sulphur species are prominent in Martian surface environments, assumed to have been introduced to the surface through volcanic activity [32]. The formation of the Mullaghwornia pyrite and organic matter is not a surface process, but it shows that if organic matter is available, it has an affinity to be preserved around pyrite. Currently, the Martian surface is highly oxidizing and therefore sulphates predominate, but early in the planet's history reducing conditions pertained. Accordingly, it has been suggested that sulphides occur on Mars [33], now preserved at depth. Sulphides are also known to be present on Mars from Martian meteorites [34,35]. Sulphide grains which are rimmed by a thin layer of poorly graphitized carbon have already been detected in carbonaceous chondrites and chondritic interplanetary dust

Table 1 Results of fluid inclusion microthermometry on fluid inclusions in calcite from a hydrothermal vein at Mullaghwornia

\begin{tabular}{|c|c|c|c|c|c|}
\hline Sample locality & Inclusion size $(\mu \mathrm{m})$ & Ts $\left({ }^{\circ} \mathrm{C}\right)$ & $\operatorname{Tfm}\left({ }^{\circ} \mathrm{C}\right)$ & $\operatorname{Tm}\left({ }^{\circ} \mathrm{C}\right)$ & Th $\left({ }^{\circ} \mathrm{C}\right)$ (to liquid) \\
\hline \multirow[t]{9}{*}{ Mullaghwornia calcite } & 12 & -63 & -49 & -15.2 & 264 \\
\hline & 12 & -66 & -50 & -15.6 & 264 \\
\hline & 14 & nd & -48 & -15.0 & 276 \\
\hline & 22 & -63 & -48 & -15.0 & 200 \\
\hline & 15 & -63 & -50 & -15.3 & 246 \\
\hline & 12 & -63 & -48 & -15.6 & 229 \\
\hline & 7 & nd & nd & nd & 205 \\
\hline & 6 & -72 & -49.8 & -16.2 & 214 \\
\hline & 3 & nd & nd & nd & 223 \\
\hline
\end{tabular}

Temperature abbreviations used: Ts = solidification, $\mathrm{Tfm}=$ first observed melting, $\mathrm{Tm}=$ final ice melting, Th = homogenization. 


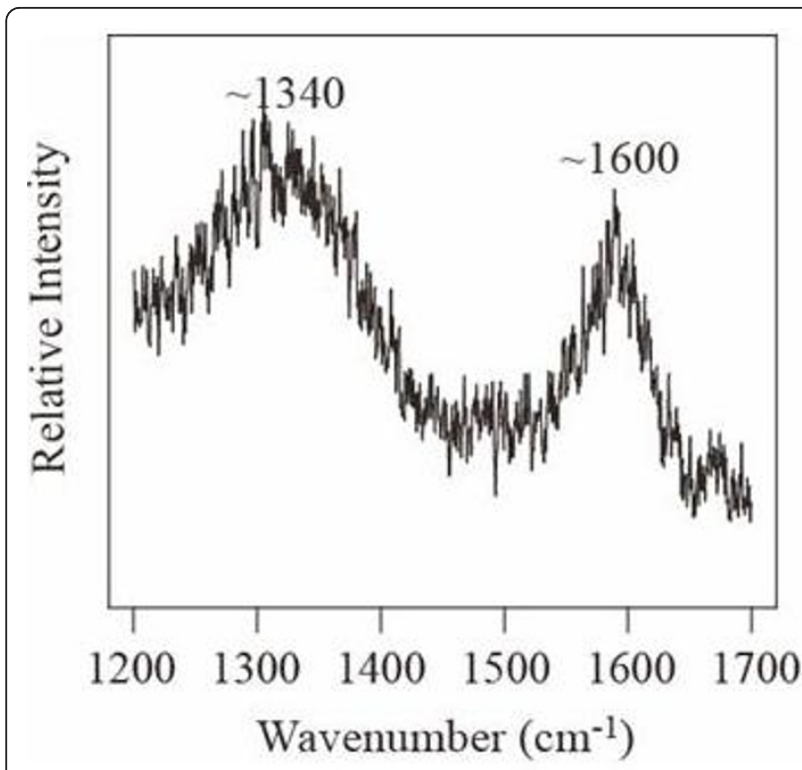

Figure 6 The Raman signature of carbon in the hydrothermal vein is poorly crystalline, with a merged G+D2 peak at around $1600 \mathrm{~cm}^{-1}$, and a D1 peak at around $1340 \mathrm{~cm}^{-1}$.

particles [36,37], and in the Tagish Lake meteorite [38]. Other evidence from the geological record that sulphides preserve organics includes sulphides in Proterozoic and Ordovician sandstones from Canada, which contain high concentrations of amino acids [39].

In addition to acting as a substrate for the concentration of organic matter, there are also other advantages of sulphides as a potential target for the detection of life. Since sulphides that are produced by microbial sulphate reduction can preserve both morphological and chemical evidence of fossil life, they are proposed as targets for the exploration for fossil life on Mars, through measurements of isotopic composition [40] and search for entrapped microbial fossils [41].

The mineralogical composition of the early Earth is debated, but metal-sulphides were probably widespread [42], and in particular iron-sulphides are found as detrital mineral components in several Archaean deposits. In terms of the iron-sulphur world theory, the relationship of the pyrite and organic matter in the hydrothermal veins of Mullaghwornia is an example from the geological record supporting the idea that the surface of pyrite acts as a substrate for the adsorption of organic molecules.

\section{Experimental methods}

The samples were prepared as thin sections and blocks for petrographic microscopy and for analyses with an XL30 environmental scanning electron microscope with a field emission gun (XL30 ESEM-FEG). The ESEM was equipped with an Oxford $x$-act energy dispersive spectrometer (EDS), backscatter electron detector (BSE) and secondary electron detector (SE). The samples were coated with a layer of ca $15 \mathrm{~nm}$ carbon prior to analyses in high vacuum. The acceleration voltage was $20 \mathrm{kV}$. The instrument was calibrated with a cobalt standard.

A $150 \mu \mathrm{m}$ thick doubly-polished wafer was prepared for fluid inclusion analysis. The fluid inclusion microthermometric analyses were performed with a Linkam THM 600 stage, mounted on a Nikon microscope, with a working range from $-196^{\circ} \mathrm{C}$ to $+600^{\circ} \mathrm{C}$. The thermocouple readings were calibrated by means of SynFlinc synthetic fluid inclusions and well-defined natural inclusions in Alpine quartz.

Raman spectroscopic analyses were conducted on thin sections and on small unpolished samples. Raman spectra were acquired by using a multichannel Dilor XY Laser Raman spectrometer. The laser source was an Innova 70 argon laser with a wavelength of $514.5 \mathrm{~nm}$ (green line). Laser focusing on the sample was performed through a petrographic microscope fitted with a $100 \times$ objective. The laser power was set at $200 \mathrm{~mW}$ at the entrance of the microscope. The spectra were accumulated in 20 increments with a measuring time of $3 \mathrm{~s}$ each. Calibration was made with respect to wavenumber using a neon laser and a silicon standard.

All the analyses were conducted at the Department of Geological Sciences, Stockholm University, Sweden.

\section{Acknowledgements}

We are grateful to Marianne Ahlbom at the Department of Geological Sciences, Stockholm University for skilled technical support, and to the Swedish National Space Board and the Knut and Alice Wallenberg Foundation for financial support. Careful reviews by two anonymous reviewers substantially improved the quality of this manuscript.

\section{Author details}

'Department of Geographical and Earth Sciences, University of Glasgow, Glasgow G12 8QQ, UK. '2Department of Geology and Petroleum Geology, University of Aberdeen, Aberdeen AB24 3UE, UK. ${ }^{3}$ Department of Geological Sciences, Stockholm University, 10691 Stockholm, Sweden.

\section{Authors' contributions}

$\mathrm{PL}$ carried out the sampling, the majority of the analytical work and drafted the manuscript. JP, NGH and CB helped with analytical work and to draft the manuscript. All authors read and approved the final manuscript.

\section{Competing interests}

The authors declare that they have no competing interests.

Received: 22 November 2010 Accepted: 7 February 2011 Published: 7 February 2011

\section{References}

1. Cairns-Smith AG, Hartman H: Clay minerals and the origin of life Cambridge: Cambridge University Press; 1986.

2. Rasmussen B, Glover JE, Foster CB: Polymerisation of hydrocarbons by radioactive minerals in sedimentary rocks: Diagenetic and Economic Significance. Society for Geology applied to Mineral deposits, Special Publications 1993, 9:490-509. 
3. Smith JV, Arnold FP, Parsons I, Lee MR: Biochemical evolution III: Polymerization on organophilic silica-rich surfaces, crystal-chemical modeling, formation of first cells, and geological clues. Proceedings of the National Academy of Sciences USA 1999, 96:3479-3485.

4. Russell MJ, Hall AJ, Cairns-Smith AG, Braterman PS: Submarine hot springs and the origin of life. Nature 1988, 336:117-117.

5. Wächtershäuser G: Pyrite formation, the first energy source for life: a hypothesis. Systematic and Applied Microbiology 1988, 10:207-210.

6. Lane N, Allen JF, Martin W: How did LUCA make a living? Chemiosmosis and the origin of life. BioEssays 2010, 32:271-280.

7. Bada JL, Lazcano A: Origin of life. Some like it hot, but not the first biomolecules. Science 2002, 296:1982-1983.

8. Wächtershäuser G: From volcanic origins of chemoautotrophic life to bacteria, archaea and eukarya. Philosophical Transactions of the Royal Society of London 2006, 361:1787-1808.

9. Pontes-Buarques M, Tessis AC, Bonapace JAP, Monte MBM, Cortés-Lopez G, de Souza-Barros F, Vieyra A: Modulation of adenosine 5'-monophosphate adsorption onto aqueous resident pyrite: Potential mechanisms for prebiotic reactions. Origins of Life and Evolution of the Biosphere 2001, 31:343-362.

10. Tessis AC, Penteado-Fava A, Pontes-Buarques M, de Amorim HS, Bonapace JAP, de Souza-Barros F, Monte MBM, Vieyra A: Pyrite suspended in artificial sea water catalyzes hydrolysis of adsorbed ATP: Enhancing effect of acetate. Origins of Life and Evolution of the Biosphere 1999, 29:361-374.

11. Cody GD, Boctor NZ, Filley TR, Hazen RM, Scott JH, Sharma A, Yoder HS Jr: Primordial carbonylated iron-sulfur compounds and the synthesis of pyruvate. Science 2000, 289:1337-1340.

12. Cohn CA, Hansson TK, Larsson HS, Sowerby SJ, Holm NG: Fate of prebiotic adenine. Astrobiology 2001, 1:477-480.

13. Hatton B, Rickard D: Nucleic acids bind to nanoparticulate iron (II) monosulphide in aqueous solution. Origins of Life and Evolution of Biospheres 2008, 38:257-270.

14. Monson B, Parnell J: Metal-organic relationships from the Irish Carboniferous. Chemical Geology 1992, 99:125-137.

15. Boyce AJ, Coleman ML, Russell MJ: Formation of fossil hydrothermal chimneys and mounds from Silvermines, Ireland. Nature 1983, 306:545-550.

16. Sevastopulo GD, Jackson PNW: Carboniferous (Dinantian). In The Geology of Ireland. Edited by: Holland CH. Dunedin Academic Press, Edinburgh; 2001:241-312.

17. Coomer PG, Robinson BW: Sulphur and sulphate-oxygen isotopes and the origin of the Silvermines deposits, Ireland. Mineral Deposita 1976, 11:155-169.

18. Fallick AE, Ashton JH, Boyce AJ, Ellam RM, Russell MJ: Bacteria were responsible for the magnitude of the world-class hydrothermal base metal sulfide orebody at Navan, Ireland. Economic Geology 2001, 96:885-890.

19. Landais P, Gize AP: Organic matter in hydrothermal ore deposits. In Geochemistry of hydrothermal ore deposits. Edited by: Barnes HL. John Wiley 1997:613-656.

20. Parnell J, Carey PF, Bottrell S: The occurrence of authigenic minerals in solid bitumens. Journal of Sedimentary Research 1994, A64:95-100.

21. Leventhal JS, Grauch RI, Threlkeld CN, Lichte FE, Harper CT: Unusual organic matter associated with uranium from the Claude deposit, Cluff Lake, Canada. Economic Geology 1987, 82:1169-1176.

22. Sawlowicz Z: Framboids: from their origin to application. Prace Mineralogiczne 2000, 88:1-80.

23. Claypool GE, Holser WT, Kaplan IR, Sakai H, Zak I: The age curves of sufur and oxygen isotopes in marine sulfate and their mutual interpretation. Chemical Geology 1980, 28:199-260

24. Machel HG: Bacterial and thermochemical sulphate reduction in diagenetic settings - old and new insights. Sedimentary Geology 2001, 140:143-175

25. Shepherd TJ, Rankin AH, Alderton DHM: A practical guide to fluid inclusion studies Glasgow. Blackie; 1985.

26. Wilkinson JJ, Everett CE, Boyce AJ, Gleeson SA, Rye DM: Intracratonic crustal seawater circulation and the genesis of subseafloor zinc-lead mineralization in the Irish orefield. Geology 2005, 33:805-808.
27. Bodnar $\mathrm{BJ}$ : Revised equation and table for determining the freezing point depression of $\mathrm{H}_{2} \mathrm{O}-\mathrm{NaCl}$ solutions. Geochimica et Cosmochimica Acta 1993, 57:683-684.

28. Goldstein RH, Reynolds TJ: Systematics of Fluid Inclusions in Diagenetic Minerals. In Society of Sedimentary Geology. SEPM Short Course. Volume 31. Tulsa; 1994.

29. Parnell J, Lindgren P: Survival of reactive carbon through meteorite impact melting. Geology 2006, 34:1029-1032.

30. Beyssac O, Goffé B, Chopin C, Rouzaud JN: Raman spectra of carbonaceous material in metasediments: a new geothermometer. Journal of Metamorphic Geology 2002, 20:859-871.

31. Wopenka B, Pasteris JD: Structural characterization of kergones to granulite-facies graphite: Applicability of Raman microprobe spectroscopy. American Mineralogist 1993, 78:533-557.

32. Bibring JP, Langevin $Y$, Mustard JF, Poulet F, Arvidson R, Gendrin A, Gondet B, Mangold N, Pinet P, Forget F, the OMEGA Team: Global mineralogical and aqueous Mars history derived from OMEGA/Mars Express data. Science 2006, 312:400-404

33. Burns RG, Fisher DS: Evolution of sulphide mineralization on Mars. Journal of Geophysical Research 1990, 95:14169-14173.

34. Greenwood JP, Riciputi LR, McSween HY, Taylor LA: Modified sulfur isotopic compositions of sulfides in the nakhlites and Chasigny. Geochimica et Cosmochimica Acta 2000, 64:1121-1131.

35. Lorand JP, Chevrier V, Sautter V: Sulfide mineralogy and redox conditions in some shergottites. Meteoritics and Planetary Science 2005, 40:1257-1272.

36. Rietmeijer FJM, Mackinnon JDR: Poorly graphitized carbon as a new cosmothermometer for primitive extraterrestrial materials. Nature 1985, 316:733-736

37. Rietmeijer FJM, Mackinnon JDR: Metastable carbon in two chondritic porous interplanetary dust particles. Nature 1987, 326:162-165.

38. Nakamura K, Zolensky ME, Tomita S, Nakashima S, Kazushige T: Hollow organic globules in the Tagish Lake meteorite as possible products of primitive organic reactions. International Journal of Astrobiology 2002, 1:179-189.

39. Nardi S, Binda PL, Baccelle LS, Concheri G: Amino acids of Proterozoic and Ordovician sulphide-coated grains from western Canada: Record of biologically-mediated pyrite precipitation. Chemical Geology 1994, 111:1-15.

40. Van Zuilen M: Stable isotope ratios as a biomarker on Mars. Space and Science Reviews 2008, 135:221-232.

41. Schieber J: Sedimentary pyrite: A window into the microbial past. Geology 2002, 30:531-534.

42. Schoonen $M$, Smirnov $A$, Cohn $C$ : A perspective on the role of minerals in prebiotic synthesis. Ambio 2004, 33:539-551.

doi:10.1186/1467-4866-12-3

Cite this article as: Lindgren et al:: A demonstration of an affinity between pyrite and organic matter in a hydrothermal setting. Geochemical Transactions 2011 12:3.

\section{Submit your next manuscript to BioMed Central and take full advantage of:}

- Convenient online submission

- Thorough peer review

- No space constraints or color figure charges

- Immediate publication on acceptance

- Inclusion in PubMed, CAS, Scopus and Google Scholar

- Research which is freely available for redistribution

Submit your manuscript at www.biomedcentral.com/submit
C Biomed Central 